\title{
YERELLİK ÖĞELERİ İÇINDE KÜRESELLEŞEN YÖNETMEN: FERZAN ÖZPETEK
}

\author{
Berna KÜÇÜK \\ İstanbul Kültür Üniversitesi, Sanat ve Tasarım Fakültesi, İstanbul, Türkiye \\ b.kucuk@iku.edu.tr \\ İrem KAHYAOĞLU \\ İstanbul Kültür Üniversitesi, Sanat ve Tasarım Fakültesi, İstanbul, Türkiye \\ i.kahyaoglu@iku.edu.tr
}

\begin{abstract}
It's a well-known fact that "globalization" is one of the most important concepts of our time. This concept can be defined as a notion uniting different people and cultures around the world. Globalization contains others concepts for completing itself. The most important concept from these concepts is "localization". Globalization and localization that complete each other, to appear suddenly in front of individuals by using daily life, politics or art and also influence individuals in many ways. In this study, the cultural signs used in the cinema of Ferzan Özpetek -turkish and also italian director- will be analyzed in the context of globalization and localization.
\end{abstract}

Keywords: Globalization, localization, cinema, cultural sign, symbols, values, traditions, Ferzan Özpetek

"Çok kültürlü olunca kafandaki açılar değişiyor. Bir
yere ait olup aslında her yere ait olmak çok güzel."

(Ferzan Özpetek)

\section{GíRiş}

Yaşamakta olduğumuz çağın en önemli kavramlarından/ olgularından birinin "küreselleşme" olduğunu söylemek yanlış olmayacaktır. Dünya üzerindeki farklı ülkelerin, insanların, kültürlerin birbirleriyle etkileşim halinde bulunması, farklı ekonomilerin ortak temeller üzerine kurulması anlamına gelen "küreselleşme" kavramı, kendini tamamlamak için başka kavramları da bünyesinde barındırmaktadır. Bu kavramlardan en önemlisi belki de "yerellik" kavramıdır. Birbirlerinin "zıttı" olarak birbirini tamamlayan bu iki kavram, gündelik yaşamdan siyasete, sanata kadar her yerde bireyin karşısına çıkmakta, hatta bireyi etkisi altına almaktadır.

"Yerellik" kavramı, anlamını hem karşıtlıktan hem de görelilikten almaktadır. Dünyanın günümüzde yaşadığı dönüşümü ile ilgili oluşturulan söylemlerde yerel terimi iki karşıtlık içinde yer bulmaktadır. Yerel, ya "küresel X yerel" ya da "ulusal X yerel" zitlı̆ğ içinde yani bir kavram çiftinin bir tarafı olarak tanımlanmaktadır. Ancak diğer yandan bu kavram çiftlerinin, içlerinde göreliliğgi barındırdığının da belirtilmesi gerekmektedir. Çünkü bu görelilik içinde yerelin karşıtı küresel olabildiği gibi ulusal da olabilmektedir. Ama başka bir açıdan bakıldığında ulusal, küreselin karşıtı olan bir yerel olarak da var olabilmektedir. Sosyolog İlhan Tekeli'nin de belirttiği gibi, bütün değiştikçe, yerel de değişmektedir. Her birey doğduğunda kendini bir yerellik içinde bulmaktadır. Yaşamın devingenliği içinde yaşanılan yerellikler değişebilmektedir. Ancak sonuçta her zaman içinde yaşanılan bir yerellik vardir.

Günümüzde var olan yerellik kavramındaki yaklaşımlarda yerel, küreselin karşıtı olarak değerlendirilmektedir. Küresel olan kapital, mal, imaj vb. akımların olduğu bir uzamdır. Bir kimliğe sahip değildir ve aynı zamanda kimliksizleştiricidir de. Bu zeminde küresel yerele 
girmekte ve onu dönüştürmektedir. Buna zıt olarak yerel ise otantiktir ve kimliğe sahip olandır. Sözü edilen bu zıtlık içinde yerelin küreselin kendini de yok ederek yayılmasına karşı durması beklenmektedir. Mevcut beklenti ise, ön görülen direnmenin toplumsal hareketler halinde ortaya çıkmasıdır (Tekeli, 2010: 167-168).

Peki, yerelliğin karşı durması beklenen küresellik kavramı tam olarak nedir? 20.yüzyılın en önemli olaylarından biri olan küreselleşme içinde ekonomik, politik, teknolojik ve sosyal alanlarda kapsamlı bir dönüşümü barındıran bir süreçtir. Bir diğer deyişle küreselleşme, ekonomik, sosyo-kültürel, siyasi ve hatta günlük yaşam boyutlarında insanları, toplumları, ülkeleri ve örgütleri etkilemektedir (Özmen, 2009: 314).

Levitt'in 1983 yılında ünlü "Globalization of Markets" makalesinde belirtmiş olduğu gibi "küreselleşme" kavramı son yirmi beş yılda gündelik konuşma içinde yer bulmuştur. Birçok tanımın yanı sıra küreselleşme; "bilginin, paranın, mal ve hizmetlerin, iş gücünün, hammaddenin, enformasyonun, teknolojinin ve fikirlerin artan hızla dünya üzerinde dolaşıma çıkması ve paylaşıma sunulması 20.yüzyılın şahit olduğu bir gelişmedir." (Yağc1, 2009: 4) Küreselleşme kavram olarak, dünyanın tek bir arenaya dönüştüğü süreci betimlemek için kullanılmaktadır.(http://books.google.com.tr/books?hl=tr\&lr=\&id=pTUs5taH6XIC\&oi=fnd\& $\mathrm{pg}=\mathrm{PA} 58 \& \mathrm{dq}=$ the + effect + of + globalization + on + local + communities + robyn + bateman $\&$ ots $=\mathrm{q}$ wKAWTX5qJ\&sig=OaqaGYqtC6IDy5-

1WB3hq4JHAYU\&redir_esc $=\mathrm{y} \# \mathrm{v}=$ onepage \&q\&f=false, erişim tarihi: 01.04.2013).

Nazım Güvenç'e göre ise, küreselleşme, sağ-sol gibi siyasi ideolojilerin dar ve öznel kalıplarının içine sığdırılamayacak kadar geniş ve nesnel bir gerçekliktir. Küreselleşmeyi kapitalizmin benimsediği yayılmacı tutumla, emperyalizmle bir tutan, ulusallığın yok edilmesi gibi gören veya gösteren düşünceler ve tavırlar son derece yanıltıcıdır (Güvenç, 1998: 305).

Yukarıda belirtilmeye çalışılan düşünceler çerçevesinde birçok araştırmacıya göre, küreselleşme aslında gelir, medya ve teknoloji olmak üzere üç ana bileşen arasında oluşan ilişkiler içerisinde var olmaktadır. Var olan bu ilişkiler ise içerisinde kültürel özellikler, gelenekler ve yerel pazarlarda gerekli olabilecek diğer unsurları da barındırabilmektedir. Küreselleşmenin medya ile bağı olan alanlarda -özellikle sanatta- kültürel özelliklerle ile kendine yer bulması söz konusudur. 7. Sanat olarak adlandırılan sinema da küreselleşme sürecinde önemli değişimler geçirmiştir. Yerelin ve küreselin ortak noktada buluşabildiği ender alanlardan biri olan sinema, bu iki önemli kavramı bünyesinde harmanlamay başarabildiği noktada çok katmanlı bir yapıya sahip olabilmektedir.

Bütün bu bilgiler ışığında yapılacak çalışmanın amacı, her gün bireylerin karşı karşıya kaldığ 1 küreselleşme ve yerellik kavramlarının sinemada nasıl yer aldığını, filmlerinde kültürel göstergelerle yerellik öğelerini sıkça kullanan ve bu özelliğiyle filmlerinin çeşitli küresel başarılar kazandığı bir yönetmen olan Ferzan Özpetek sineması üzerinden incelemektir. Çalışmada öncelikle küresellik ve yerellik kavramları çeşitli kuramcıların temelinde irdelenmeye çalışılacak, ardından küresellik ve sinema ilişkisine değinilecektir. Kurulacak kuramsal çerçeve etrafinda Ferzan Özpetek'in IMDB bazında en çok puan alan filmleri, yönetmenin küresellik-yerellik kavramlarıyla ilişkili olarak kullandığı kültürel göstergeler temelinde incelenecektir.

\section{KÜLTÜR KAVRAMI TEMELİNDE KÜRESELLEŞME VE 7. SANAT SINNEMA İLişKISİ}

Kültür emperyalizminin kendine en çok yer bulduğu alanlardan biri sinemadır. Kültürel göstergeler sinema içinde oldukça kullanılmaktadır. Küresellik ve yerellik kavramlarının kültürel göstergeler aracılığıyla sinemada nasıl yer aldığını incelemeden önce, kültürün ne anlama geldiğine bakmak gerekirse; kültür kavramı "eğilim göstermek" ya da "sürdürmek" 
anlamına gelen "colero" kelimesinin kökü olan Latince "cultura"dan gelmiştir (Nardal1, Ay, 2009: 108).

Terry Eagleton ise kültürü en geniş anlamıyla, "genler yoluyla birbirimize aktaramadığımız her şeydir” şeklinde tanımlamaktadır (Eagleton’ten aktaran Günay, Sönmez, 2012: 110). Kültür kavramının kullanımına ve yorumlanmasına bakıldığında ise, Eco'ya göre, "bir göstergenin yorumu kültürel ya da anlamsal bir birimdir. Her hangi bir kültürde bu birimler bir karşıtlık dizgesi içinde düzenlenir. Bu ilişki durumu genel anlamsal dizge olarak adlandırılır" (Eco, 1998: 154). Kültürel göstergeler de tıpkı diğer göstergeler gibi farklılıklar, zıtlıklar içinde anlam kazanmaktadırlar. Bir kültürde yer alan göstergeler kendi aralarında ilişki kurmalarının yanı sıra, diğer kültürlere ait göstergelerle de ilişki içinde bulunmaktadırlar. $\mathrm{Bu}$ etkileşimin sonucu olarak, iki kültüre ait değişik göstergeleri birbirleriyle karşılaştırmak olanağı bulunmaktadır (Günay, Sönmez, 2012: 113).

Kültürel göstergelerin farklı yorumlanmasının sebebi, Ella Shohat ve Robert Stam'ın da belirttiği gibi, algıların zamana, uzama ve bağlama bağlı olarak değişmesidir. Bir filme ait aynı imgeler ya da sesler farklı toplumlar için farklı algıları ortaya çıkarabilmektedir. Genel anlamda, küreselleşme ve ulusallık arasındaki ilişkiler "resmi simetri" tarafından şekillendirilmektedir. Ancak bu durum aslında, gerçek bir asimetridir. Bütün durumlarda, kültürler iletişim süreçlerinde ulusal özelliklerini (farklılıklarını) kaybetme eğilimindedirler. Bunun sonucunda da göstergesel olarak ulusal olmayan hale gelmişlerdir. Ancak yaşadıkları bu kayıp, ulusal kaynağa sahip olmadıkları için değildir. Tersine kimlikler, kültürler ve ulusal ilgiler başarılı araçlardır. Ancak bu şekilde, "küreselleşme"nin özellikle de sinema alanında simetrik olmayan bir süreç olduğu ortaya çıkmaktadır (Hedetoft, 2005, http://is.muni.cz/el/1421/jaro2012/FAV196/um/32133503/HjortMackenzie_Cinema_and_Nat ion.pdf\#page=277 erişim tarihi: 22.04.2013: 262-264).

Kültür kavramı temelinde sinema ve küresellik ilişkisi düşünüldüğü zaman akıllara ilk "Hollywood" gelmektedir. Kültürel emperyalizm korkusu sinema alanında özellikle de sinemanın ilk yıllarında Amerikan sineması ile Fransız sineması arasında yaşanmıştır. Kamuoyunu etkileme ve değerleri şekillendirme gücü nedeniyle, Hollywood filmlerinin hegemonyası uluslararası siyasal konularda bile oldukça önemli bir yere sahip olmuştur. Diğer yandan, Ulusötesi (Transnational) sinemanın en önemli temsilcisi olan Hollywood'un yanı sıra diğer ülke sinemaları da yerellikleri içinde küreselleşebilmektedir.

$\mathrm{Bu}$ açıdan, ulusötesi olarak ifade edilen yönetmenlerin sineması ayrıcalıklı kültürel yapılandırma ile artan işbirliği içindedir. Film-yapımcılarının coğrafi-ulusal konumları bilişsel ve düşünsel basmakalıp katı sistemlere karşı durmanın garantisi olarak görülmektedirler. Bu yaklaşım özellikle Ferzan Özpetek'in Hamam filminde de görülebilmektedir. Bu filmde Özpetek geleneksel kodları (yerellik öğeleri) oldukça fazla kullanmıştır (Girelli, 2007, http://www.ingentaconnect.com/content/intellect/nc/2007/00000005/00000001/art00002, erişim tarihi: 30.03.2013).

\section{YERELLİK-KÜRESELLİK BAĞLAMINDA FERZAN ÖZPETEK FİLMLERINIIN İNCELENMESI}

\section{Ferzan Özpetek Kimdir?}

“İtalya'da Türk, Türkiye’de İtalyanım...”

1959 yllında Istanbul'da doğan Ferzan Özpetek 1976 yılında, Roma'daki La Sapienza Üniversitesi'nde Sinema Tarihi eğitimi almıştır. Accademia Navona'da ve Accademia d'Arte Drammatica'da Silvio D'Amico yönetimindeki sanat tarihi ve kostüm derslerine devam eden Özpetek, 1982 yllında Julian Beck ile birlikte Yaşayan Tiyatro'da çalıştıktan sonra "Scusate il ritardo"da Massimo Troisi'nin ve "Son Contento"da Maurizio Ponzi'nin asistanlığın yapmıştır. Asistanlık süreci yönetmenin sinemada uzmanlaşmasının başlangıcı olmuştur. 
Yönetmenin ilk filmi olan Hamam, 1997 Cannes Film Festivali’nde "Yönetmenlerin Onbeş Günü" tarafindan keşfedilmiş ve hem Italya hem de diğer ülkelerde eleştirmenlerin ve sinemaseverlerin beğenisini kazanmıştır. Yönetmenin ikinci filmi Harem Suare ise 1999 yllında Cannes Film Festivali'nin Resmi Seçkisine seçildi ve Toronto, Palm Springs ve Londra festivallerinden de resmi davet almıştır. Ayrıca Özpetek ilk iki filmi ile yakaladı̆̆ başarıyı izleyen filmlerinde de sürdürerek İtalya'nın en çok izlenen yönetmenlerinden biri olmuştur.

Yönetmenin Filmleri: Hamam, 1997- Harem Suare, 1999-Cahil Periler, 2000-Karşı Pencere, 2002-Kutsal Yürek, 2005-Bir Ömür Yetmez, 2007-Mükemmel Bir Gün, 2008-Şahane Misafir, 2012 (Mithat Alam Film Merkezi Söyleşi, Panel ve Sunum Yıllı̆̆ 2009).

Çalışmada İncelenecek Ferzan Özpetek Filmleri ve Künyeleri;

(7.29) - La finestra di fronte/ Karşı Pencere (2003)

(7.19) - Le fate ignoranti/ Cahil Periler (2001)

(6.90) - Mine vaganti/ Serseri Mayılar (2010)

(6.80) - Hamam (1997) (http://www.imdb.com/name/nm0654858/filmorate)

\section{KARŞI PENCERE}

\section{Filmin Konusu:}

'Karşı Pencere', dokuz yıldır evli ve iki çocuklu genç bir kadın olan Giovanna ile kocası Filippo'nun tesadüfen yolda yaşı bir adamla karşılaşmalarıyla başlar, olaylar hafızasını kaybeden yaşlı adamın hayatlarına girmesiyle gelişir, bununla birlikte genç kadının da yaşamı değişmeye başlar. Evliliği pek yolunda gitmeyen Giovanna'nın karşı pencereden gözetlediği komşusuna duyduğu platonik aşk ve yaşlı adamın geçmişten gelen aşk hikayesi ikisinin de yaşamlarını etkiler. Genç kadın için artık yaşamını sorgulama zamanı gelmiştir (http://www.sinemalar.com/film/923/karsi-pencere, erişim tarihi: 12.04.2013).

\section{Filmin künyesi:}

\begin{tabular}{|l|ll|}
\hline Filmin Adı: Karşı Pencere & Tür: & Romantik, Dram \\
Yönetmen: Ferzan Özpetek & Süre: & 106 dakika \\
Görüntü Yönetmeni: Gianfilippo Corticelli & Dağıtımcı: Warner Bros. \\
Senaryo: Ferzan Özpetek, Gianni Romoli & Oyuncular: Giovanna Mezzogiorno \\
Kurgu: Patrizio Marone & Massimo Girotti \\
Müzik: Andrea Guerra & Raoul Bova \\
Yapım yılı ve ülkesi: 2003, İtalya-İngiltere- & Serra Yılmaz \\
Türkiye & \\
Yapımcı: Tilde Corsi, Gianni Romoli & \\
\hline
\end{tabular}

(http://arsiv.ntvmsnbc.com/news/247859.asp?cp1=1, erişim tarihi: 01.04.2013.)

\section{CAHIL PERILER}

\section{Filmin Konusu:}

Antonia ve Massimo, Roma yakınlarındaki bir sayfiyede normal bir hayat süren, 10 yılı aşkın süredir evli bir çifttir. Massimo'nun bir araba kazası sonucu ölmesi ile, Antonia için herşey bir anda alt üst olur. Massimo ölümünün ardından çok sayıda anı ve bir de şüphe bırakmıştır. Acaba Massimo'nun, evlilikleri süresince bir başka kadınla ilişkisi olmuş mudur? Antonia bu merakla kocasının geçmişinin araştırmaya başlar. Sonuç, hayal edebileceğinin de ötesinde sürprizlerle doludur (http://www.sinemalar.com/film/1827/cahil-periler, erişim tarihi: 29.03.2013).

\section{Filmin künyesi:}




\begin{tabular}{|l|l|}
\hline Filmin Adı: Cahil Periler & Andrea Renzi \\
Yönetmen: Ferzan Özpetek & Gabriel Garko \\
Görüntü Yönetmeni: Pasquale Mari & Erika Blanc \\
Senaryo: Ferzan Özpetek, Gianni Romoli & Rosaria De Cicco \\
Sanat Yönetmeni: Bruno Cesari & Lucrezia Valia \\
Oyuncular: Margherita Buy & Luca Calvani \\
Stefano Accorsi & Koray Candemir \\
Serra Yılmaz & \\
\hline
\end{tabular}

(http://www.sinemalar.com/film/1827/cahil-periler, erişim tarihi: 29.03.2013).

\section{SERSERI MAYINLAR}

\section{Filmin Konusu:}

İtalya'nın güneyinde bir makarna fabrikasının sahibi olan Cantoneler, son derece varlıklı bir ailedir. Ailenin erkek çocuklarından biri, Tommaso, Roma'daki okulunu bitirir ve evine geri döner. Bu geri dönüş oldukça önemlidir, çünkü Tommaso tüm ailesini bir arada toplayıp eşcinsel olduğunu açıklamaya karar vermiştir. Bu gerçeği erkek kardeşi Antonio'ya açıklayarak aile işlerini bırakıp yazar olmaya karar verdiğini söyler. Sırrını açıklamaya hazır olan Tommaso beklenmedik bir sürpriz karşısında başarısız olur. Erkek kardeşi Antonio da eşcinseldir ve bunu açıklamıştır. Bu durum karşısında aileyi sıkıntılı zamanlar beklemektedir (http://www.beyazperde.com/filmler/film-179492/).

Filmin Künyesi:

\begin{tabular}{|l|ll|}
\hline Filmin Adı: Serseri Mayınlar & Tür: & Dram, Komedi, Romantik \\
Yönetmen: Ferzan Özpetek & Süre: & 110 Dak. \\
Yapımcı: Domenico Procacci, Gianluca & Oyuncular: Riccardo Scamarcio \\
Leurini & Nicole Grimaudo \\
Senaryo: Ferzan Özpetek, Ivan Cotroneo & & Daniele Pecci \\
Vizyon Tarihi: 26 Mart 2010 & Carolina Crescentini \\
Yapımı: 2010 - İtalya & & Lunetta Savino \\
\hline
\end{tabular}

(http://www.sinemalar.com/film/37464/serseri-mayinlar, erişim tarihi: 04.04.2013.)

\section{HAMAM}

\section{Filmin Konusu:}

34. Antalya Film Festivali'nde en iyi film, yönetmen ve müzik ödüllerini almıştır. Film, yıllar önce İtalya'yı terk edip İstanbul'da yaşamaya başlayan teyzesinin öldüğünü ve kendisine miras olarak bir hamam bıraktı̆̆ını öğrenen, meslek hayatında başarılı, evlilik hayatındaysa problemli genç mimar Francesco'nun İstanbul'a gelişi ve Mehmet adlı gençle ilişkisi anlatmaktadır. (http://www.sinemalar.com/film/922/hamam, erişim tarihi: 25.03.2013.)

Filmin Künyesi:

\begin{tabular}{|l|l|}
\hline Filmin Adı: Hamam & Yapımı: \\
Yönetmen: Ferzan Özpetek & Türkiye, İspanya - İtalya, \\
Yapımcı: Marco Risi, Cengiz Ergun & Oyuncular: Şerif Sezer \\
Senaryo: Ferzan Özpetek & Başak Köklükaya \\
Vizyon Tarihi: 24 Ekim 1997 & Halil Ergün \\
Tür: Dram, Romantik & Alper Kul \\
& Zerrin Arbaş \\
\hline
\end{tabular}

(http://www.sinemalar.com/film/922/hamam, erişim tarihi: 25.03.2013.)

\section{Ferzan Özpetek'in Seçilen Filmlerinin Kültürel Göstergeler Bağlamında İncelenmesi}

Kültürü oluşturan öğelere bakıldığında, Amerikalı antropolog George P. Murdock'un (1967) yaptığ çalışmalar sonucu kültür kavramının her toplumda 72 adet öğesi (adlar, aile, batıl inançlar, dini kurallar, bayramlar, cenaze adetleri, evlilik, hediyeleşme hukuk, yemek, yemek saati, ticaret şekli, şaka yapma, tedavi olma... gibi) olduğu ortaya çıkmakta ve bu öğeler 
Murdock tarafından "Kültürün Evrensel Öğeleri” olarak adlandırılmaktadır (Nardalı, Ay, 2009: 110).

Evrensellik kavramının karşısında yer alan bir kavram olan ulusal kültürün ne olduğu incelendiğinde şu şekilde bir tanımla karşılaşmak mümkündür: "Ulusal kültür, değerler, inançlar, normlar ve ulusal grupların davranışsal dokuları"dır. Kültürle ilgili geleneksel bilgiler Hollandalı araştırmacı Geert Hofstede'nin geliştirmiş olduğu "soğan kabuğu" kuramının yansımasıdır. Hofstede kültürü "bir grubun üyelerini ya da insan kategorisini diğerinden ayırt eden aklın toplu programlaması" şeklinde tanımlamaktadır. Değerler Hofstede'e göre, sembolleri, kahramanları ve ritüelleri içeren kültürel pratikler aracıllğıyla manifesto edilen kültürün görülmeyen yanıdır. Kültürel değerlerin uygulamaları yönlendirdiği savıyla kültür, değerler ve pratikler arasındaki ilişkileri "Soğan Kabuğu Diyagramı" ile görselleştirmiştir. Diğer yandan Hofstede'e göre, kültür "ç̧evrenin insan yapımı parçasıdır" (Javidan, House ve ark. 2006: 899, http://www.palgravejournals.com/jibs/journal/v37/n6/pdf/8400234a.pdf, erişim tarihi:25.03.2013).

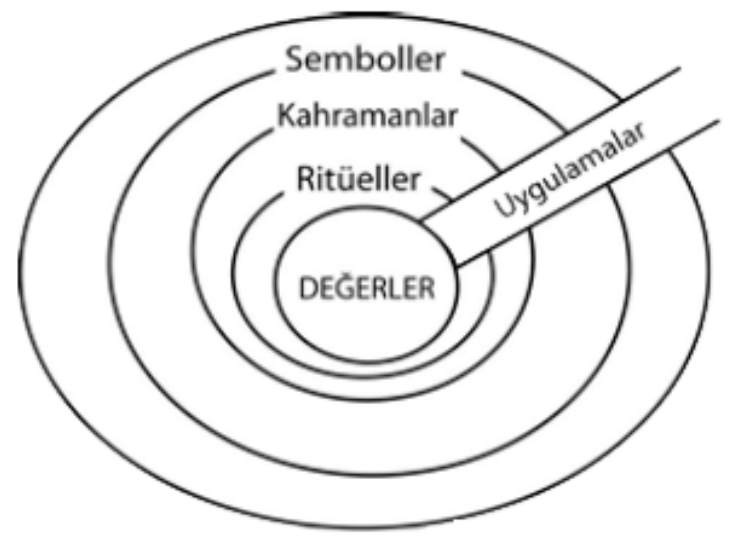

Şekil 1- Hofstede’in "Soğan Kabuğu” Modeli (Hoftstede, 2005).

Hofstede'in geliştirmiş olduğu kuram çerçevesinde filmlerin içerisinde yer alan küresel ve/veya yerel olgular kültürel göstergeler temelinde dört ana başlık etrafında ele alınacaktır:

Simgeler: Simgeler bağlama göre hem var olanı hem de var olmayanı ifade etmektedir. Belli anlamları yükler ve diğerlerini dışlarlar. Karşıtlık ilişkisi kurarak anlamı gizli bir şekilde aktarırlar. Örneğin haç "Hristiyan olanları" gösterirken, aynı zamanda olmayanları da belirtmiş olmaktadır. Anlamı gizli biçimde aktarmaktadırlar. Bir diğer yandan ise simgeler, anlam aktarma süreci içinde sözcükleri, biçimleri, el-kol devinimlerini de kullanmaktadır. Konusu geçen simgeler uygulandıkları alan ile ilgili olarak işlem yüklenmektedirler (Küçükerdoğan, 2009: 20).

Kahramanlar: Birey, iletişim sürecinin temelinde yer almakta ve kimi zaman ileti aktarımında kimi zaman ise iletinin algılanması sürecinde etkili olmaktadır. Reklam iletileri gibi alıcı üzerinde doğrudan etki yaratma amacına sahip olan iletilerde ise aktaran kişinin, yani kahramanın diğer işlevi de alıcıyı etkileyerek mal ya da hizmeti satın almaya yönlendirmektir (Küçükerdoğan, 2009: 61).

Adetler/ Gelenekler (Ritüeller): Gelenekler "farklı kültürel ortamlarda bireylerin sözlü olmayan davranışlarıdır." Kuşaktan kuşağa anlatılan söylenceler, olaylar, alışkanlıklar geleneklere örnek olarak verilebilmektedir. Törenler (ritüeller) ise, "davranışların simgesel biçimleridir ve belli davranış biçimleri yaratmak ya da sürdürmek amacıyla yapılırlar, örneğin etkileme amacı taşırlar." Törenlerde paylaşım, birliktelik gibi duygular ön plandadır. Bu törenlere katılan kişiler çoğu zaman aynı kültürden olan kişilerdir. Birbirleriyle ilişkilidirler (Küçükerdoğan, 2009: 58-59). 
Değerler: "Değerler ve davranışlar, bir kültürde neyin doğru neyin yanlış, neyin güzel neyin çirkin, neyin önemli neyin önemsiz vs. olduğunun göstergesi olarak tanımlanmaktadır. Birey kendisine öğretilen bu değer yargılarına göre hareket etmekte, aksi takdirde toplumdan dışlanmaktadır. Normlar ise yaptırım gücü olan kurallar bütünü olup kültürel değerler, normlar aracılığıyla davranışları etkilemektedir “(Odabaşı’ndan aktaran Nardalı, Ay, 2009: 110).

Hofstede'e göre ise; "Değer araçları kişinin olması gerek hissinin betimlerken, uygulamalar (pratikler) ise karşıdaki kişinin ne hissettiğini tanımlamaktadır. Bu iki kavram arasındaki ayrım sadece araştırmacıların kavramlarında bulunmamaktadır. Aynı zamanda kişilerin akıllarında da bulunan bir ayrımdır" (Javidan, House ve ark. 2006: 900, http://www.palgravejournals.com/jibs/journal/v37/n6/pdf/8400234a.pdf, erişim tarihi:25.03.2013).

$\mathrm{Bu}$ tanım ışığında, değerlerin tutumlardan önce gelmekte olduğu ve ilk olarak tutumları ardından ise davranışları etkilediği belirtilebilmektedir. Sosyal yapı, din, dil, eğitim ve ekonomik durum gibi unsurlar, değerlerin oluşmasında önemli role sahiptir. Bu nedenle farklı din, dil ve ırk gibi özellikler taşıyan bireylerin, farklı değerlere sahiptir. Konuyla ilgili örnek vermek gerekirse, Arap, İspanyol ve Latin toplumlarının zaman ve değer yargıları ile Amerikan veya Alman toplumlarının zaman ve değer yargıları birbirinden farklıdır (Nardalı, Ay, 2009: 110-111).

Örneğin Amerikan kültürü içinde bulunan çok yeme özelliği diğer kültürlere göre oldukça farklıdır. Rapaille'in belirttiğine göre, diğer kültürlerde de Amerikan tarihinde yaşanan açlık ve açlıktan ölme gibi sıkıntılar yaşanmıştır. Ancak, bu sıkıntılara rağmen yine de birçoğunun "depolama" arzusunu hafifletecek başka etkenler yaşanmıştır. İtalyan kültürü üzerinde ise, aristokrasinin güçlü etkileri bulunmaktadır. Kısaca, "bir aristokrat hiçbir zaman bir büfede tıkınmayacak, hiç bir zaman yemek yerken acele etmeyecektir. O tüm lokmaların tadını çıkarır, lezzeti ve uyumu takdir eder”. İtalyan toplumunun yemeğe ilișkin bu aristokratik tutumu, bütün katmanlara sızmıştır. İtalyanların, statülerinden bağımsız bir şekilde, konu yemek olduğunda "güçlü bir zarafet anlayışları" bulunmaktadır. Onlara göre aşırı yemek, "lezzeti takdir etme becerisini" yok etmektedir (Rapaille, 2011: 146-147). Bu noktada, "kültürler bireysel boyutlarda değildir. Bir bütündürler ve sahip oldukları mantıksal boyut kişilerin bireysel dinamikleri ile anlaşılamamaktadır" (Javidan, House ve ark. 2006: 900, http://www.palgrave-journals.com/jibs/journal/v37/n6/pdf/8400234a.pdf,erişim

tarihi:25.03.2013). Ayrıca pek çok araştırmacıya göre ise, kültürü oluşturan alışkanlıklar, değerler ve inanışlar, insanoğlunun davranışları ve gelişiminde kesinlikle önemli bir role sahiptir (Javidan, House ve ark. 2006:908,http://www.palgravejournals.com/jibs/journal/v37/n6/pdf/8400234a.pdf,erişim tarihi:25.03.2013).

Bu bağlamda çalışma içerisinde "küresellik" ve "yerellik" kavramlarıyla ilişkilendirilen yönetmen Ferzan Özpetek'in IMDB bazında en çok puan alan, Karşı Pencere, Cahil Periler, Hamam ve Serseri Mayınlar adlı filmleri içerdiği kültürel göstergeler temelinde, kahramanlar, gelenekler, simgeler ve değerler çerçevesinde şu şekilde incelenmektedir; 
Tablo 1: Karşı Pencere

\begin{tabular}{|c|c|c|c|}
\hline Kahramanlar/ Kişiler & $\begin{array}{l}\text { Gelenekler/Törensel } \\
\text { Davranışlar }\end{array}$ & Simgeler & Değerler \\
\hline $\begin{array}{l}\text {-Giovanna } \\
\text { Mezzogiorno(Giovanna) } \\
\text {-Flippo Nigro (Flippo) } \\
\text {-Massimo Girotti (Yaşlı } \\
\text { adam) } \\
\text {-Serra Yılmaz (Emine) }\end{array}$ & $\begin{array}{l}\text {-Aile yemeği } \\
\text { dikdörtgen masa (sofra } \\
\text { düzeni) } \\
\text {-Tv karşısında maç } \\
\text { seyretmek (Flippo) }\end{array}$ & $\begin{array}{l}\text {-Emine Karakteri } \\
\text { (Türk oyuncu } \\
\text { Serra Y1lmaz) } \\
\text {-Yaşlı adamın } \\
\text { kanaviçe yatak } \\
\text { örtüsü }\end{array}$ & $\begin{array}{l}\text {-Aile } \\
\text {-Paylaşım } \\
\text {-Yardımseverlik } \\
\text { (Ailenin hafızasını } \\
\text { kaybeden yaşlı } \\
\text { adamı evine alması) } \\
\text {-Bağlılık } \\
\text {-Aşk } \\
\text {-Tutku } \\
\text {-İhanet } \\
\text {-Komşuluk ilişkisi }\end{array}$ \\
\hline
\end{tabular}

Tablo 2: Cahil Periler

\begin{tabular}{|c|c|c|c|}
\hline Kahramanlar/Kişiler & $\begin{array}{l}\text { Gelenekler/Törensel } \\
\text { Davranışlar }\end{array}$ & Simgeler & Değerler \\
\hline $\begin{array}{lr}\text {-Margherita } & \text { Buy } \\
\text { (Antonia) } & \\
\text {-Andrea } & \text { Renzi } \\
\text { (Massimo) } & \\
\text {-Stefano } & \text { Accorsi } \\
\text { (Michele) } & \\
\text {-Serra Yilmaz } & \text { (Serra) } \\
\text {-Gabriel } & \text { Garko } \\
\text { (Ernesto) } & \\
\text {-Erika Blanc (Veronica) } & \text {-Koray Candemir (Emir) }\end{array}$ & $\begin{array}{l}\text {-Japon ölüm } \\
\text { seremonisi } \\
\text {-Türkçe şark1 } \\
\text {-Uzun dikdörtgen } \\
\text { yemek masas1 } \\
\text {-Yemek tarifi vermek } \\
\text { (Türk karakter Serra } \\
\text { tarafindan) } \\
\text {-Kahve yapmak }\end{array}$ & $\begin{array}{l}\text {-Mumlar-çiçek } \\
\text {-Sunak/Buda } \\
\text { (dini simge- } \\
\text { yerellik öğesi) } \\
\text {-Serra } \\
\text { karakterinin } \\
\text { Türkçe } \\
\text { konuştuğu sahne } \\
\text { (dilsel gösterge) } \\
\text { - İtalyan tipi } \\
\text { mutfak } \\
\text {-Ajda Pekkan } \\
\text {-Japon müziği } \\
\text {-Cezve } \\
\text {-Kimono } \\
\text {-“Kahve } \\
\text { yapayım mı?” } \\
\text { (Dilsel gösterge) } \\
\text {-Japon kadının } \\
\text { geleneksel } \\
\text { kıyafeti }\end{array}$ & $\begin{array}{l}\text {-Aile } \\
\text {-Birlik } \\
\text {-Aşk } \\
\text {-İhanet } \\
\text {-Arkadaşlık İlişkisi } \\
\text {-Yardım } \\
\text { severlik (Hasta } \\
\text { bakımı) } \\
\text {-Komşuluk İlişkisi- } \\
\text { misafirperverlik }\end{array}$ \\
\hline
\end{tabular}


Tablo 3: Serseri Mayınlar

\begin{tabular}{|l|l|l|l|}
\hline $\begin{array}{l}\text { Kahramanlar } \\
\text { Kişiler }\end{array}$ & $\begin{array}{l}\text { Gelenekler/Törensel } \\
\text { Davranışlar }\end{array}$ & Simgeler & Değerler \\
\hline -Riccardo & -Cenaze töreni & -Gelinlik (küresel & -Zenginlik \\
Scamarcio & -Düğün töreni & simge) & -Özlem \\
(Tommaso & & -Gümüş Takım & -Sevgi \\
Cantone) & & -Siyah beyaz aile & -Bağl1lik \\
-Nicole & fotoğrafları & -Aile \\
Grimaudo (Alba & & - "Doğunun en & \\
Brunetti) & değerli kumaşlarını & \\
-Alessandro & & getirdim.” (Dilsel & \\
Preziosi - & & gösterge) & \\
(Antonio Cantone & & -Yuvarlak masada & \\
-Ennio & akşam yemeği, & \\
Fantastichini & & makarna ve şarap & \\
(Vincenzo & & - Akşam yemeğinde & \\
Cantone & fikra anlatımı (Dilsel & \\
-Lunetta Savino & & gösterge) & \\
(Stefania Cantone & & -Müzik kullanımı ve & \\
) & & Sezen Aksu (işitsel & \\
& & gösterge) & \\
& & & \\
\hline
\end{tabular}

Tablo 4: Hamam

\begin{tabular}{|c|c|c|c|}
\hline $\begin{array}{l}\text { Kahramanlar/ } \\
\text { Kişiler }\end{array}$ & $\begin{array}{l}\text { Gelenekler/Törensel } \\
\text { Davranışlar }\end{array}$ & Simgeler & Değerler \\
\hline $\begin{array}{l}\text {-Alessandro } \\
\text { Gassman } \\
\text { (Francesco) } \\
\text {-Francesca } \\
\text { d'Aloja (Marta ) } \\
\text {-Carlo Cecchi } \\
\text { (Oscar) } \\
\text {-Halil Ergün } \\
\text { (Osman) } \\
\text {-Serif Sezer } \\
\text { (Perran) } \\
\text {-Mehmet Günsür } \\
\text { (Mehmet) } \\
\text {-Basak } \\
\text { Köklükaya } \\
\text { (Fusün) }\end{array}$ & $\begin{array}{l}\text {-“Yar saçların lüle } \\
\text { lüle” Türküsü } \\
\text {-Kahve (sabah } \\
\text { İtalyan geleneği) } \\
\text {-Dansöz rakı sofras1 } \\
\text {-Türk şarkıc1 } \\
\text { İtalyanca şark1 } \\
\text { söylüyor. } \\
\text {-Hamam kültürü }\end{array}$ & $\begin{array}{l}\text {-Dantel masa örtüsü } \\
\text {-Başörtüsü ( yemeni) } \\
\text {-Dansöz } \\
\text {-Pavyon } \\
\text {-Kilise } \\
\text {-Çinili hamam } \\
\text {-Takunya-peştemal } \\
\text {-İnce belli bardakta } \\
\text { çay } \\
\text {-“Bu akşam bütün } \\
\text { meyhanelerini } \\
\text { dolaştım } \\
\text { İstanbul'un"şarkısı } \\
\text { (İşitsel Gösterge) } \\
\text {-Esnaf (Köfteci } \\
\text { Refik) }\end{array}$ & $\begin{array}{l}\text {-Aile } \\
\text {-Bağlılık } \\
\text {-Sevgi } \\
\text {-Umut } \\
\text {-Özlem }\end{array}$ \\
\hline
\end{tabular}




\section{SONUÇ}

Fransız ekonomi profesörü Serge Latouche (2001:24-25) küreselleşmenin kültürü yok ettiğini savunmaktadır. Çünkü ona göre, kültür, ekonomik emperyalizm ve ekonominin emperyalizm nedeniyle yerinin müzeler olduğu düşünülen folklor bir kavram konumuna düşürülmektedir (Tutal, 2005: 35). Ancak diğer taraftan küreselleşme ile ilgili yapılan bir tanım da şu şekildedir: "Küreselleşme: hangi alanda olursa olsun ekonomiden sanata, bilimden iletişime herhangi bir çalışmada/üretimde/ yapımda dünya çapında geçerliliği/ağırlığı/öncülü̈̆̈̈ olan normların/ ölçütlerin dikkate alınması veya etkili hale gelmesi, benimsenmesi; dünyaya açılarak yerelliğin/ulusallı̆̆ın reddedilmeksizin dışına çıkılması ve evrensellikle bağdaştırılmast/birleşmesidir" (Güvenç, 1998: 318).

$\mathrm{Bu}$ noktada üzerinde durulması gereken kavram belki de, dünyada, yerelliklerin birbirinden kopuk bağlantılar şeklinde küreselleşmenin dönüştürdüğü deneyimler olarak yaşandığı savının açıklaması olan "melezlik" kavramıdır. Melezlik "dünyanın farklı yerlerindeki kültürlerin birbirine karışmasıdır (...) Bu açıdan Amsterdam'da Faslı kızların Tayland Boksu yapmasl, Londra'daki Asya rap müziği, Irlanda bageli (bir tür simit), Çin tacosu (Meksika Yemeği) gibi fenomenleri kabullenme girişimidir" (Tomlinson'dan aktaran Tutal, 2006: 74).

Dünyanın farklı yerlerinde, hayatın ne kadar farklı yaşandığ 1 ve farklı bölgelerdeki insanların -gündelik yaşam göz önüne alınarak- her şeyden önce, kendi “yerel" kültürlerinin taleplerine karşılık verdikleri unutulmaması gereken bir gerçekliktir (Wallerstein, 2013: 186). Alman filozof Martin Heidegger'in "dasein" (bir yerde var olmak) kavramından yola çıkılırsa, bir insanın varlığının ancak bir yerellikte anlam kazandığını belirtmek yanlış olmayacaktır (Tekeli, 2010: 143).

"Yerel”e ilişkin olarak elde edilen bulgular, bireylerin yereli nasıl tanımladığı ile ilgilidir. Bu doğrultuda,

$\begin{array}{ll}\text { - } & \text { Yerel nesneleriyle, objeleriyle bilinir; } \\ \text { - } & \text { Yerel insanlarıyla bilinir; } \\ \text { - } & \text { Yerel iç ve diş ilişkileriyle bilinir. }\end{array}$

Eğer yerel bu özellikleriyle biliniyorsa ve tanımlanıyorsa yerelin betimlenmesi de bu öğeler kurularak yapılmalıdır (Tekeli, 2010: 170). Ferzan Özpetek de filmlerinde küresellik ve yerellik kavramlarını kültürel göstergeler temelinde bu şekilde kurgulamıştır.

Amerikalı sosyolog Immanuel Wallerstein'e göre, global kültür diye bir "şey"in varlığını kabul etmeyenler olabilmektedir. "Fakat bu haşarı cinin gerçekte var olduğuna inanan çok sayıda insan var. Bu kavram, kimilerine göre bir yarı tanr, kimilerine göre ise şeytanın vücut bulmuş hali. Ama öyle görünüyor ki, tüm bu insanlar için bu, bir gerçeklik" (Wallerstein, 2013: 183). Bu ifadesiyle Walerstein'ın, aslında insanların kültürel normlarının ihlal edildiğini ortaya koymasının bile bir kültürün yaşadığının göstergesi olduğunu belirttiği oldukça açıktır.

Kültürel farklılıklar aynı bilginin farklı biçimlerde işlenmesine neden olmaktadır (Rapaille, 2011: 6). Her kültür kendine özgü gelenekler, törensel davranışlar, simgeler ve değerlere sahiptir. Karşı Pencere ve Cahil Periler filmlerine "aile yemeği geleneği" çerçevesinde bakıldığında dikdörtgen masa etrafinda toplanan bireyler görülmektedir. Aktarılmak istenen anlam ise, aile içi iletişimi güçlü tutmak, dostluk, arkadaşlık ve akrabalık ilişkilerini pekiştirmek, sevgi, bağlılık ve paylaşımı arttırmaktır.

Yönetmenin neredeyse tüm filmlerinde rol alan Türk oyuncu Serra Yılmaz da Ferzan Özpetek sineması içerisinde kültürel bir simge ve bir yerellik öğesi olarak karşımıza çıkmaktadır. Ayrıca oyuncunun Türk kimliği ile rol aldığı ve orijinal dili İtalyanca olan filmlerin kimi sahnelerinde Türkçe konuşturulduğu da dikkat edilmesi gereken bir başka noktadır.

Gelenekler ve törensel davranışlar çerçevesinde yönetmenin üçüncü filmi olan Cahil Periler'e bakıldığında ise, izleyicinin bazı sahnelerde bir Japon Ölüm Seremonisi ile karşılaştırıldığ 
görülmektedir. Filmin ana karakterlerinden olan ve olayların akışını değiştiren Massimo'nun ölümü ardından üzüntüsüne tanık olunan Japon yardımcı kadın, bu törensel davranışın kahramanıdır. Seremoninin gerçekleştirildiği uzam ise içeriğinde, ölünün fotoğrafı, mum, tütsü ve ölünün eşyaları gibi çeşitli simgesel öğeleri barındırmaktadır.

Yönetmenin filmlerinin yerel göstergelerinden olan Türk oyuncu Serra Yılmaz'ın Türk insanının önemli değerlerinden olan komşuluk ilişkilerinin ve misafirperverliğin önemini vurguladığı ve özellikle Karşı Pencere ve Cahil Periler filmlerinde bunun temsili olarak sunulduğu açıkça görülmektedir. Kimi sahnelerde İtalyan komşularının çocuklarına baktığı, kimi sahnelerde ise elinde yemek tabağı ile komşu ziyareti yaparak yemek tarifi verdiği sözü geçen değerleri örneklendirmektedir.

Filmin en önemli işitsel göstergelerinden olan müzik kullanımı ise yerellik bağlamında altı çizilmesi gereken en önemli noktalardan biridir. Bu bağlamda ilk akla gelen isim "Sezen Aksu'dur". Yönetmen birçok filminde sanatçının müziklerini İtalyan yaşamı içerisine aktarmayı başarmıştır. Ayrıca yerellik göstergesi olan Sezen Aksu'nun "Kutlama" adlı şarkısı, Serseri Mayınlar filminin final sahnesinde düğün ve cenaze törenine arka fon oluşturmaktadır. Müzik ile ilişkisi olan bir diğer yerellik öğesi ise Cahil Periler filminde hasta odasının asılı olan Ajda Pekkan posteridir. Bu görsel gösterge izleyiciyi hem sanatçının kendisine hem de şarkılarına götürmektedir.

Sanatçının ilk filminde (Hamam) ise, en önemli gösterge olan hamamın kendisi filmin temel yerellik öğesidir. Ayrıca filmde dansöz kullanımı, rakı sofrasının kurulması, iki kültürü bir araya getiren Türkçe ve İtalyanca şarkılar, gelenekleri temsil ederken, dantel masa örtüsü, başörtüsü, takunya, peştamal, ince belli bardakta içilen çay gibi kültürel göstergeler de simgeleri temsil etmektedir.

Bu noktada Özpetek'in filmlerinde de görüldüğü gibi, yerellikler aslında küresellik karşıtı olarak bulunmamaktadır. Tersine, yerellik bir zenginleștirme aracı olarak kültürlerarası etkileşimi daha sağlıklı hale getirmekte, küreselleşme kavramını güçlendirmektedir. Böylece küreselleşme, emperyalizmin korkulan özelliklerinden bağımsız, dünya üzerindeki kültürlerin birbirlerine katkı sağlaması anlamına gelebilecektir. Bunun ütopik bir durum olmadığına verilebilecek en önemli örnek ise, yine Özpetek'in filmlerinde -sadece Türk yerel öğeleri değil- pek çok yerel kültürü bir arada vererek küresel başarılara imza atmasıdır.

\section{KAYNAKÇA}

ECO, U. (1998). Ortaçağ Estetiğinde Sanat ve Güzellik İstanbul: Can Yayınları.

GIRELLI, E. (2007). Transnational Orientalism: Ferzan Özpetek's Turkish dream inHamam (1997). New Cinemas: Journal of Contemporary Film.S.23-38.

http://www.ingentaconnect.com/content/intellect/nc/2007/00000005/00000001/art00002,

GÜNAY, D ve PARSA, A. (2012). Görsel Göstergebilim-İmgenin Anlamlandırılmas1. İstanbul: Es Yayınları.

GÜVENÇ, N. (1998). Küreselleşme ve Türkiye, İstanbul: BDS Yayınları.

HEDETOFT, U. (2005). Contemporary Cinema, Between cultural globalisation and national interpretation. Cinema and Nation. England: Taylor \& Francis e-Library. s. 262-279. http://is.muni.cz/el/1421/jaro2012/FAV196/um/32133503/HjortMackenzie_Cinema_and_Nat ion.pdf\#page $=277$.

HOFTSTEDE, Geert ve Gert Jan Hoftstede.(2005). Cultures and Organizations. 2. Basim. Mc. Graw Hill.

JAVIDAN, M. HOUSE, R. ve ark. (2006). Conceptualizing and measuring cultures and their consequences: a comparative review of GLOBE's and Hofstede's approaches. Journal of International Business $\quad$ Studies. 897-914 http://www.palgravejournals.com/jibs/journal/v37/n6/pdf/8400234a.pdf. 
KÜÇÜKERDOĞAN, R. (2009). Reklamda Kültürlerarası1lı, İstanbul: Es Yayınları. Mithat Alam Film Merkezi Söyleşi. (2009). Panel ve Sunum Yıllığı, İstanbul. ÖZMEN, A. (2009). Küresel ve Çok Kültürlü Pazarlarda Marka Konumlandırma. Stratejik Küresel Pazarlama. İstanbul: Eflatun, s.314-342.

RAPAILLE, C. (2011). Kültür Kodu. İstanbul: FGD Yayınc1lık.

SAMIR, D. (2004). The Changing Face of Globalization. Sage: New Delhi. http://books.google.com.tr/books?hl=tr\&lr=\&id=pTUs5taH6XIC\&oi=fnd\&pg=PA58\&dq=the + effect + of + globalization + on+local + communities + robyn + bateman\&ots=qwKAWTX5qJ\&sig $=$ OaqaGYqtC6IDy5-1WB3hq4JHAYU\&redir_esc $=\mathrm{y} \# \mathrm{v}=$ onepage $\& \mathrm{q} \& \mathrm{f}=$ false.

TEKELİ, İ. (2010). Gündelik Yaşam, Yaşam Kalitesi ve Yerellik Yazıları, İstanbul: Tarih Vakfi Yurt Yayınları.

TUTAL, N. (2006). Küreselleşme, İletişim, Kültürlerarası1lık. İstanbul: Kırmızı.

WALLERSTEIN, I. (2013). Bilginin Belirsizlikleri, İstanbul: Matani Basın ve Yayıncılık. YAĞCI, M. (2009). Küresel Pazarlama Stratejisinin Gelişimi ve Genel İlkeler. Stratejik Küresel Pazarlama. İstanbul: Eflatun, s.4-28.

http://arsiv.ntvmsnbc.com..

http://www.beyazperde.com.

http://www.sinemalar.com. 